\title{
Single atom gold catalysts for low-temperature CO oxidation
}

\author{
Botao Qiao a,†, Jin-Xia Liang b,†, Aiqin Wang a, Jingyue Liu c,\#, Tao Zhang a,* \\ a State Key Laboratory of Catalysis, Dalian Institute of Chemical Physics, Chinese Academy of Sciences, Dalian 116023, Liaoning, China \\ b Guizhou Provincial Key Laboratory of Computational Nano-Material Science, Guizhou Education University, Guiyang 550018, Guizhou, China \\ c Department of Physics, Arizona State University, Tempe, Arizona 85287, United States
}

\section{A R T I C L E I N F O}

Article history:

Received 1 June 2016

Accepted 23 August 2016

Published 5 October 2016

\section{Keywords:}

Gold

Single atom catalyst

CO oxidation

Stability

Low temperature

\begin{abstract}
A B S T R A C T
Low-temperature CO oxidation is important for both fundamental studies and practical applications. Supported gold catalysts are generally regarded as the most active catalysts for low-temperature CO oxidation. The active sites are traditionally believed to be Au nanoclusters or nanoparticles in the size range of $0.5-5 \mathrm{~nm}$. Only in the last few years have single-atom Au catalysts been proved to be active for $\mathrm{CO}$ oxidation. Recent advances in both experimental and theoretical studies on single-atom Au catalysts unambiguously demonstrated that when dispersed on suitable oxide supports the $\mathrm{Au}$ single atoms can be extremely active for $\mathrm{CO}$ oxidation. In this mini-review, recent advances in the development of Au single-atom catalysts are discussed, with the aim of illustrating their unique catalytic features during $\mathrm{CO}$ oxidation.
\end{abstract}

(c) 2016, Dalian Institute of Chemical Physics, Chinese Academy of Sciences. Published by Elsevier B.V. All rights reserved.

\section{Introduction}

Low-temperature CO oxidation is of significant importance, not only with regard to fundamental studies as a prototypical reaction but also in terms of practical applications, such as automobile emission control and the purification of gas streams derived from petrochemical industry [1]. Among various types of catalysts developed for this reaction, supported gold catalysts, with gold nanoparticles (NPs) finely dispersed on oxides, have attracted extensive attention over the past decades since Haruta discovered their extremely high activity, even at temperatures as low as $-70{ }^{\circ} \mathrm{C}[2-4]$. It is now generally accepted that oxide-supported Au NPs are the most active catalysts for CO oxidation, although a few reports have suggested that $\mathrm{Rh} / \mathrm{TiO}_{2}$ [5] and $\mathrm{Co}_{3} \mathrm{O}_{4}$ [6-8] showed similar activities at temperatures below $-80^{\circ} \mathrm{C}$.
The CO oxidation on supported Au catalysts has been a paradigm in the last two decades. This seemingly simple reaction is difficult to understand on supported Au catalysts. Many factors, including the size of the gold NPs, the valence state of the gold, and the nature of the support oxide as well as the interactions between gold and the support, can dramatically affect the activity of CO oxidation. These effects are not only fundamentally intriguing but also practically important because an in-depth understanding of why and how these factors influence the catalytic performance would be helpful for refining the synthesis of such catalysts, thus promoting their performance. Of more importance, the learning gained from the studies of supported Au catalysts may provide guidance for the design and development of other supported noble metal catalysts [9]. In fact, the reference role of study on gold catalysts has been realized and there are an increasing number of examples that

\footnotetext{
* Corresponding author. Tel: +86-411-84379015; Fax: +86-411-84685940; E-mail: taozhang@dicp.ac.cn

\# Corresponding author. E-mail: Jingyue.Liu@asu.edu

+ These authors contribute equally to this work.

DOI: 10.1016/S1872-2067(16)62529-9 | http://www.sciencedirect.com/science/journal/18722067 | Chin. J. Catal., Vol. 37, No. 10, October 2016
} 
demonstrate the development of new Pt-group metal catalysts based on the knowledge and understanding gained from the studies on supported Au catalysts [5,9-11].

Among various factors that affect the activity of CO oxidation, the size of $\mathrm{Au}$ NPs might be the most important one [12-16]. In his recent "Spiers Memorial Lecture" [16], Haruta summarized the active species for CO oxidation and suggested that the optimum size of Au NPs for CO oxidation may range from 0.5 to $5 \mathrm{~nm}$ (Figure 1). In contrast, $\mathrm{Au}^{3+}$ and $\mathrm{Au}^{+}$cations are believed to be less active, by approximately one to two orders of magnitude. Studies on model catalysts have also suggested that supported $\mathrm{Au}$ atoms are less active compared with Au clusters containing more than eight atoms [17]. Therefore, it has generally been thought that supported single $\mathrm{Au}$ atoms, if they are active at all, are much less active for CO oxidation than the Au NPs and the subnano Au clusters. Despite this, recent experimental data have demonstrated that Au single-atom catalysts (SACs) can be active for several reactions [18], such as the water-gas-shift (WGS) [19-22], methanol steam reforming (MSR) [23] and ethanol dehydrogenation reactions [24]. Especially, the progresses in both theoretical and experimental studies over the last few years have suggested that single $\mathrm{Au}$ atoms supported on suitable oxides can be as active for low-temperature CO oxidation as Au NPs and subnano clusters [25-31]. These studies suggested that oxide-supported single $\mathrm{Au}$ atoms could provide a new type of catalyst for CO oxidation and other reactions.

The recent development of aberration-corrected scanning transmission electron microscopy (AC-STEM) techniques, especially the high-angle annular dark-field (HAADF) imaging technique, has made it possible to routinely image noble metal single atoms dispersed over many types of catalyst supports [32]. The AC-HAADF imaging technique is the only characterization technique that can provide fundamental and exclusive information regarding the presence, dispersion, and location of individual metal atoms on the support surfaces, and has proved indispensable to optimizing the synthetic protocols of SACs. The AC-HAADF technique is most valuable for examining heavy-element metal atoms dispersed onto light-element supports due to its special image formation mechanism [32]. Further developments are needed to unambiguously identify the

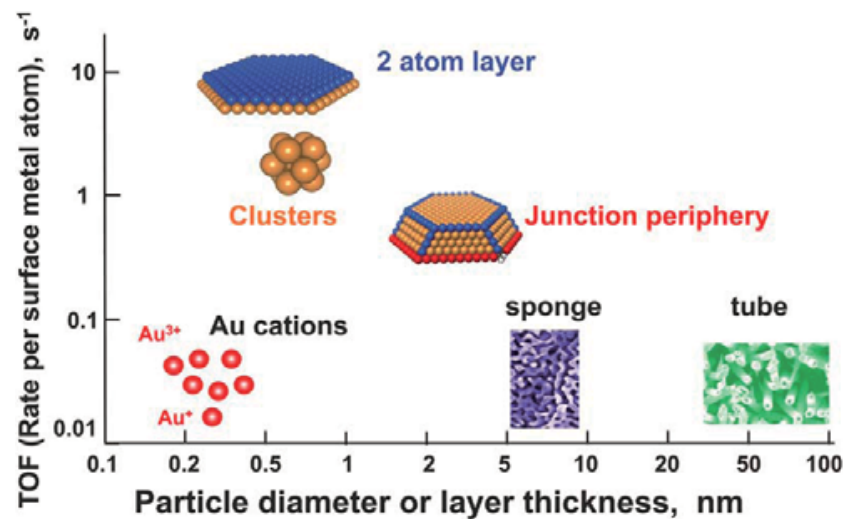

Fig. 1. Turn-over-frequency (TOF) of CO oxidation at room temperature for various types of supported Au catalysts. Reprinted with permission from Ref. [16]. Copyright 2011, Royal Society of Chemistry. nature of light-element metal atoms on supports.

In this mini-review, we discuss the recent advances in $\mathrm{Au}$ SACs, with the aim of illustrating their unique catalytic features for CO oxidation.

\section{Recent advances in Au SACs for CO oxidation}

\subsection{Experimental progress}

Gates' group has performed an intensive study on the catalytic performance of cationic $\mathrm{Au}$ species for $\mathrm{CO}$ oxidation [33-40], including isolated $\mathrm{Au}^{+}$atoms $[33,36]$. In their studies, the catalytic activity for CO oxidation decreased with a decreasing fraction of the cationic Au existed either on NPs [34] or in the form of an isolated mononuclear complex species [33], suggesting a role of cationic $\mathrm{Au}$ as the catalytic sites for $\mathrm{CO}$ oxidation. Mononuclear complexes were stable during the CO oxidation reaction [33,36]; their activities were, however, relatively low and the TOF (turn-over-frequency) was generally at the level of $0.01 \mathrm{~s}^{-1}$ or less. Such a TOF value is at least one order of magnitude lower than that of the most active supported $\mathrm{Au}$ catalysts with a TOF values in the range of $0.1-1 \mathrm{~s}^{-1}$. Their much lower activity seems to suggest that isolated $\mathrm{Au}$ atoms are less active compared with Au nanoclusters and Au NPs [16]. However, it should be noted that many factors may account for the observed low activity of the isolated atomic Au species. First, in their studies they employed non- or less reducible support materials such as zeolite, $\mathrm{MgO}$ and $\mathrm{La}_{2} \mathrm{O}_{3}$. The nature of the support surface can significantly affect the CO oxidation activity of supported Au catalysts $[4,41]$. With a reducible oxide as support, better $\mathrm{CO}$ oxidation performance has been observed due to the support's role in either activating $\mathrm{O}_{2}$ species [41] or directly participating in the reaction through a redox process $[9,42]$. Therefore, the support materials used in their studies may have not made a synergistic contribution to the activity of the mononuclear cationic Au species. Second, in their studies the mononuclear species are complexes containing ligands. Although extend X-ray adsorption fine structure (EXAFS) characterizations have suggested that Au can directly bond to the support via one or two $\mathrm{Au}-\mathrm{O}$ bonds [37], the ligands may still have been present in the final catalyst, because there was no direct evidence showing that the ligands were removed during the catalytic reactions. Whether the presence of the ligands had a negative effect on the observed activity is still unclear. In their later studies, they found that the samples became more active after being treated at elevated temperatures [39,43-45]. This could be ascribed to the formation of more active gold clusters, but a possible effect resulting from the removal of the ligands cannot be ruled out completely. Therefore, from the limited data available, it is difficult to unambiguously determine whether or not Au SACs have catalytic activity similar to, or even better than, that of Au NPs or clusters.

In contrast to the above studies, we recently developed a series of oxide-supported single-atom Au catalysts prepared by simply depositing $\mathrm{Au}$ atoms on various oxide supports with atomic dispersion [25-27]. These catalysts were proven highly 
active for CO oxidation, with much higher specific rates and TOF values, similar to those of small Au NPs on the same supports. The observation that supported $\mathrm{Au}$ single atoms and $\mathrm{Au}$ NPs possess similar TOF values, calculated on the assumption that the active sites are all Au atoms in the SACs as opposed to only the surface atoms of Au NPs, suggests that isolated $\mathrm{Au}$ atoms dispersed on suitable oxide supports can be as active as those $\mathrm{Au}$ atoms on the corners, steps and/or surfaces of Au NPs on the same oxide supports. The much higher specific rates, calculated on the basis of total metal mass, also demonstrate the higher atom efficiency of the SACs. More importantly, these SACs showed better stability compared with their NP/cluster counterparts.

To directly synthesize metal oxide-supported Au single atoms by the traditional wet chemistry approach one generally needs to use low levels of the Au precursor species. Thus, gold atoms on $\mathrm{FeO}_{x}$ with very low loading amount of $\mathrm{Au}(<0.03$ $w t \%$ ) were used to synthesize the Au SACs [25]. The $\mathrm{FeO}_{x}$ was pre-synthesized by a co-precipitation method and then the $\mathrm{Au}$ atoms were directly deposited to allow the Au atoms dispersed all on the surfaces of the $\mathrm{FeO}_{x}$ support. These catalysts are active for CO oxidation at room temperature and show a TOF of $\sim 0.5 \mathrm{~s}^{-1}$, a value similar to that of the most active $\mathrm{Au} / \mathrm{FeO}_{x}$ catalysts (in the range of $0.5-1 \mathrm{~s}^{-1}$ ) prepared by depositing $2-3 \mathrm{~nm}$ colloidal $\mathrm{Au}$ NPs onto the pre-synthesized $\mathrm{FeO}_{x}$ so as to ensure the sole, or at least primary, existence of Au NPs [46]. By comparing the activity of these two sets of catalysts, it is evident that the single $\mathrm{Au}$ atoms dispersed on $\mathrm{FeO}_{x}$ can be as active as the $\mathrm{Au}$ NPs in the size range of 2-3 $\mathrm{nm}$. Furthermore, the TOF values obtained from the SACs were similar to those of the $\mathrm{Au}$ clusters and NPs in the optimum size range of 0.5-5 nm (approximately $1 \mathrm{~s}^{-1}$ ). This work represented the first-ever proof that Au SACs can be as active as the most active Au NPs, although not as active as the reported bilayer structure Au species $[15,47]$. It should be noted that the amount of residual $\mathrm{Cl}^{-}$in the above work is unknown. It is believed that the residual $\mathrm{Cl}^{-}$generally has a negative effect on supported Au catalysts, especially for the $\mathrm{CO}$ oxidation reaction. However, recent studies show that, in the case of iron oxide-supported $\mathrm{Au}$ catalysts, the $\mathrm{Cl}^{-}$ anion has negligible or even positive effects, depending on the preparation method and the residual amounts of the anion $[48,49]$. Therefore, the possible effects of residual $\mathrm{Cl}^{-}$needs to be clarified by further investigations. More interestingly, the authors have also found that the Au SACs are not only active but also extremely stable for CO oxidation at temperatures above $200{ }^{\circ} \mathrm{C}$ (Figure 2) [25]. This observation is intriguing because it is generally believed that highly dispersed atoms are much less thermostable and thus easy to sinter to form small clusters and/or NPs [50]. There are two possibilities that may account for the experimentally observed excellent stability. The first is that the $\mathrm{Au}$ atoms interact more strongly with the support than Au NPs do. Another possibility is that, given the low density of $\mathrm{Au}$ atoms on the support surface, even if the Au atoms move during a catalytic reaction, they have a small probability to encounter one another to form clusters or NPs. However, the latter possibility can be primarily excluded by comparing the behaviors of different supported Au catalysts. First,

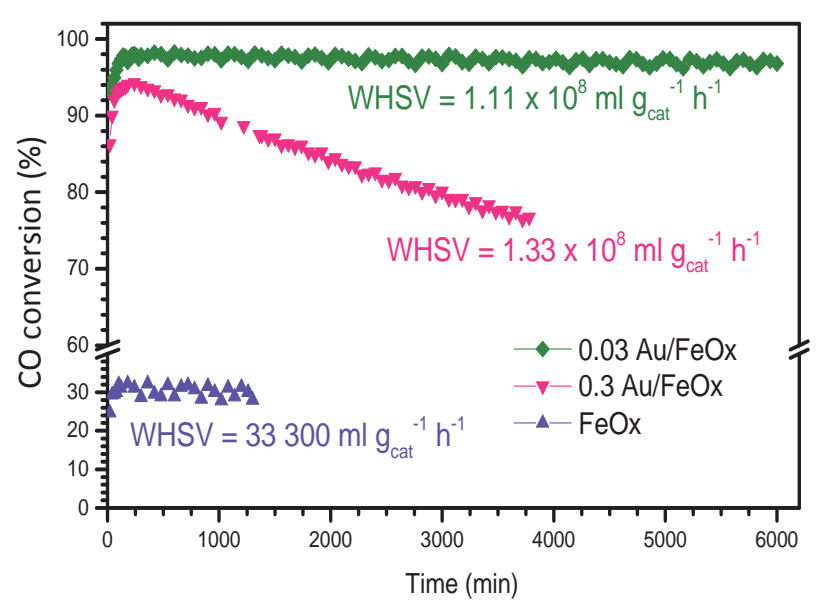

Fig. 2. Stability tests of the $0.03 \mathrm{Au}_{1} / \mathrm{FeO}_{x}$ and $0.3 \mathrm{Au} / \mathrm{FeO}_{x}$ catalysts for $\mathrm{CO}$ oxidation at $200{ }^{\circ} \mathrm{C}$. The test for the $\mathrm{FeO}_{x}$ support is also shown as a reference. Test conditions: 1 vol $\% \mathrm{CO}+1$ vol $\% \mathrm{O}_{2}+98$ vol $\% \mathrm{He} . \mathrm{Re}-$ printed with permission from Ref. [25]. Copyright 2015, Springer.

the number density of $\mathrm{Au} \mathrm{NPs}$ in the $0.3 \mathrm{wt} \% \mathrm{Au} / \mathrm{FeO}_{x}$ reference sample should be lower than the density of $\mathrm{Au}$ atoms in the $0.03 \mathrm{wt} \% \mathrm{Au} / \mathrm{FeO}_{x}$ sample because each $\mathrm{Au} \mathrm{NP}$ (2-5 nm in size) contains much more than 10 atoms. However, after the stability test, the Au NPs exhibited significant sintering, suggesting that even with sparse distribution the Au NPs still sinter. Second, after the stability test, the number density of the isolated $\mathrm{Au}$ atoms in the $0.3 \mathrm{wt} \% \mathrm{Au} / \mathrm{FeO}_{x}$ (which was higher than that in the $0.03 \mathrm{wt} \% \mathrm{Au}_{1} / \mathrm{FeO}_{x}$ ) was not changed appreciably, suggesting that the isolated Au atoms may be anchored more strongly on $\mathrm{FeO}_{x}$ than are Au NPs. To better understand and explain the excellent stability of the Au SACs, density functional theory (DFT) calculations were performed, and the results demonstrated that the experimentally observed excellent stability originated from the strong covalent metal-support interaction (CMSI) between $\mathrm{Au}$ atoms and the $\mathrm{FeO}_{x}$ support, as detailed in Section 2.2.

In the study described above [25], although Au SACs showed high activity for $\mathrm{CO}$ oxidation even at ambient temperature, the total CO conversion was only realized at $160{ }^{\circ} \mathrm{C}$ due to the very low Au loading, making the catalyst less attractive for practical applications at low temperatures. Subsequent work by the same group focused on dispersing $\mathrm{Au}$ atoms on $\mathrm{Co}_{3} \mathrm{O}_{4}$ which is itself a highly active CO oxidation catalyst [6-8]. Despite the activity of pure $\mathrm{Co}_{3} \mathrm{O}_{4}$ for $\mathrm{CO}$ oxidation, the $\mathrm{Au} / \mathrm{Co}_{3} \mathrm{O}_{4}$ catalysts are usually slightly less active and less studied compared with other oxides such as $\mathrm{FeO}_{x}$ and $\mathrm{TiO}_{2}$-supported $\mathrm{Au}$ catalysts $[4,51]$. However, when isolated Au single atoms were used, the $\mathrm{Au}_{1} / \mathrm{Co}_{3} \mathrm{O}_{4}$ was found to be extremely active for $\mathrm{CO}$ oxidation even at ambient temperatures that even with only $0.05 \mathrm{wt} \% \mathrm{Au}$ loading it could realize total CO conversion, as shown in Figure 3 [26]. To the best of our knowledge, for the first time, CO total conversion has been realized with such a low loading amount of $\mathrm{Au}$ at ambient temperature. The specific reaction rate was estimated, after subtracting the contribution of the $\mathrm{Co}_{3} \mathrm{O}_{4}$ support, to be approximately 25 molco $_{\mathrm{g}_{\mathrm{Au}}}{ }^{-1} \mathrm{~h}^{-1}$, about 10 times higher than the definition of "highly active catalyst" proposed 


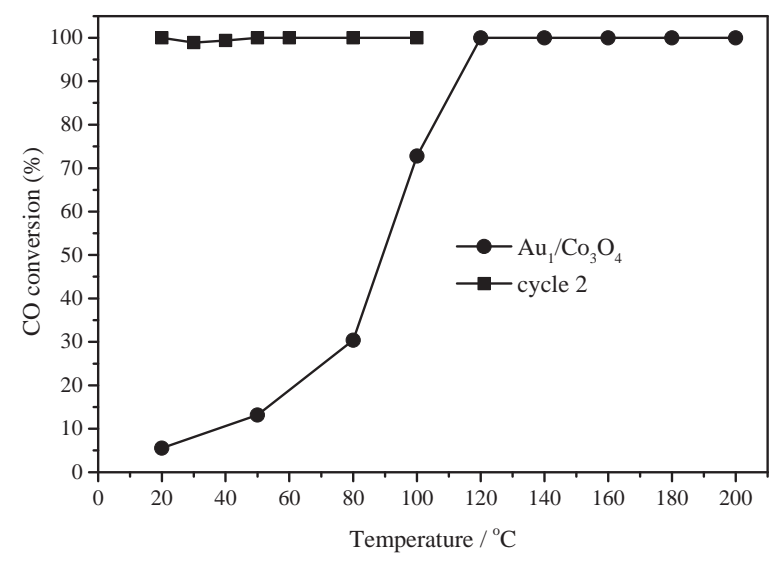

Fig. 3. $\mathrm{CO}$ conversion as a function of reaction temperature for $\mathrm{CO}$ oxidation on $\mathrm{Au}_{1} / \mathrm{Co}_{3} \mathrm{O}_{4}$ catalyst. Reaction conditions: 1 vol\% CO + 1 vol\% $\mathrm{O}_{2}$ balance with $\mathrm{He}$; total flow rate $=33.3 \mathrm{~mL} / \mathrm{min}, 50 \mathrm{mg}$ catalyst diluted with $100 \mathrm{mg} \mathrm{Al}_{2} \mathrm{O}_{3}$, space velocity $=40000 \mathrm{~mL} \mathrm{~g}_{\text {cat }}{ }^{-1} \mathrm{~h}^{-1}$. Reprinted with permission from Ref. [26]. Copyright 2015, Elsevier.

by Schuth [52]. The TOF of this catalyst, calculated from the specific rate based on $100 \%$ dispersion, was approximately 1.4 $\mathrm{s}^{-1}$, which is similar to [9] or even higher than that of the most active $\mathrm{Au}$ catalysts [46], except the bilayer structure of $\mathrm{Au}$ $[15,47]$. It should be noted that, however, this catalyst has to undergo a high temperature reaction before it became highly active at ambient temperatures, suggesting some form of "conditioning" of the fresh SAC during the CO oxidation reaction occurred. In addition, while this catalyst is extremely active, it is less durable under long-term test at ambient temperature. Cycling tests and heat treatments with different gases have suggested that this deactivation is reversible and so may originate from the accumulation of carbonates and/or subtle changes in the oxidation states of the $\mathrm{Au}$ or Co species during the catalytic reaction. The fact that the catalyst remained active after calcination at $400{ }^{\circ} \mathrm{C}$ and that the Au was atomically dispersed confirm that the deactivation was not due to sintering of isolated $\mathrm{Au}$ single atoms.

Ceria $\left(\mathrm{CeO}_{2}\right)$ is another widely used support for highly active supported $\mathrm{Au}$ catalysts. As early as 2003, Flytzani-Stephanopoulos' group, by using a sodium cyanide leaching method, for the first time, found that only isolated metal $(\mathrm{Au} / \mathrm{Pt})$ cations/clusters that strongly bonded to the La-doped $\mathrm{CeO}_{2}$ support are the active sites for the WGS reaction [53]. Those metal NPs that could be easily leached from the support by sodium cyanide were therefore proposed to be only spectators. This synthetic approach to the fabrication of SACs has provoked various discussions [16] owing to the relatively lower activity of the resulting catalysts compared with that obtained from the $\mathrm{Au} / \mathrm{CeO}_{2}$ catalysts prepared by conventional wet chemistry methods [54], and to the fact that the possible formation of sodium gold cyanide compounds may affect the observed catalytic performance [55,56]. Subsequent reports from the same group [19-22,57], however, provided clear evidence that isolated $\mathrm{Au}(\mathrm{Pt})$ cations bonded with $\mathrm{OH}^{-}$groups were active for WGS reaction. The ambiguity about the true nature of the active sites suggests that a precise identification and comparison of the activity of the single-atom and NP active sites is quite complicated. Nevertheless, despite the debates on the nature of the active sites, it is speculated that Au SACs are either inactive or much less active than their NP/cluster counterparts for $\mathrm{CO}$ oxidation because the reported activity of leached catalysts was very low and was dramatically increased after heat-treatment in $\mathrm{H}_{2}$ due to the formation of small clusters/NPs [58].

Our group, following a similar approach to that used to prepare $\mathrm{Au}_{1} / \mathrm{FeO}_{x}$ and $\mathrm{Au}_{1} / \mathrm{Co}_{3} \mathrm{O}_{4}$, developed a $\mathrm{CeO}_{2}$-supported $\mathrm{Au}$ $\mathrm{SAC}\left(\mathrm{Au}_{1} / \mathrm{CeO}_{2}\right)$ with various $\mathrm{Au}$ loading levels [27]. Different from the $\mathrm{FeO}_{x}$ and $\mathrm{Co}_{3} \mathrm{O}_{4}$ materials, the prepared $\mathrm{CeO}_{2}$ nanocrystallites possessed numerous Ce vacancies as suggested by the HAADF-STEM images [27]. Therefore, the Au loading amounts in these new materials should be higher provided that the $\mathrm{Au}$ atoms can be anchored to the Ce vacancy sites [28]. In fact, the characterization and reaction results demonstrated that a catalyst with a $0.3 \mathrm{wt} \%$ Au loading still primarily consisted of isolated $\mathrm{Au}$ atoms without the presence of any $\mathrm{Au}$ clusters and NPs. This loading level is much higher than those for $\mathrm{Au}_{1} / \mathrm{FeO}_{x}$ and $\mathrm{Au}_{1} / \mathrm{Co}_{3} \mathrm{O}_{4}$ catalysts, 0.03 and $0.05 \mathrm{wt} \%$, respectively, suggesting that the creation of Ce vacancies on the support is crucial to the fabrication of SACs with high levels of metal loading. Similar to the $\mathrm{Au}_{1} / \mathrm{FeO}_{x}$ systems, the $\mathrm{Au}_{1} / \mathrm{CeO}_{2}$ catalysts provided TOF values close to, and specific rates much higher than, those of their NP counterparts. Moreover, it was discovered that the $\mathrm{Au}_{1} / \mathrm{CeO}_{2}$ exhibited very low reactivity for the oxidation of $\mathrm{H}_{2}$ molecules, even at relatively high temperatures, possibly due to their inability of dissociative adsorption of $\mathrm{H}_{2}$, as shown in Figure 4. The TOF for pure $\mathrm{H}_{2}$ oxidation on $\mathrm{Au}_{1} / \mathrm{CeO}_{2}$ was approximately two orders of magnitude lower than that on the Au NPs supported on ceria. As a consequence, the TOF for pure $\mathrm{H}_{2}$ oxidation at $120^{\circ} \mathrm{C}$ was at least two orders of magnitude lower than that for $\mathrm{CO}$ oxidation at $80{ }^{\circ} \mathrm{C}$ on the $\mathrm{Au}_{1} / \mathrm{CeO}_{2} \mathrm{SAC}$. In contrast, the TOF was only three to six times lower than that for $\mathrm{CO}$ oxidation on Au NPs supported on ceria. The inability of dissociative adsorption of $\mathrm{H}_{2}$ on $\mathrm{Au}_{1} / \mathrm{CeO}_{2}$ was further verified by DFT calculations. This unique feature is ideal for the preferential oxidation of $\mathrm{CO}$ in $\mathrm{H}_{2}$-rich gas stream

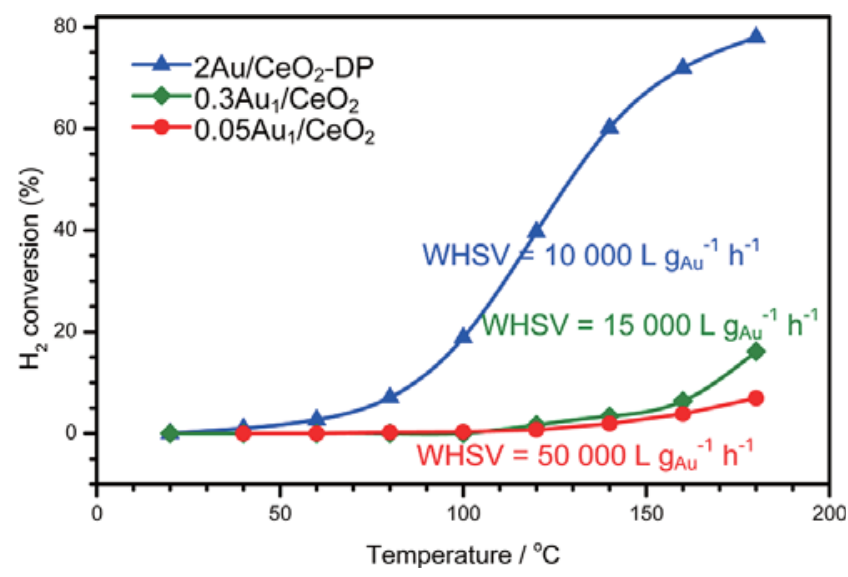

Fig. 4. $\mathrm{H}_{2}$ conversion as a function of temperature for $\mathrm{H}_{2}$ oxidation on $\mathrm{Au} / \mathrm{CeO}_{2}$ catalysts. Reaction condition: $1 \mathrm{vol} \% \mathrm{H}_{2}+1$ vol $\% \mathrm{O}_{2}$ balanced with He. Reprinted with permission from Ref. [27]. Copyright 2015, American Chemical Society. 
(PROX) reaction [27]. The $\mathrm{Au}_{1} / \mathrm{CeO}_{2} \mathrm{SAC}$ can realize total $\mathrm{CO}$ conversion in a $\mathrm{H}_{2}$-rich gas stream at either 50 to 100 or 70 to $120{ }^{\circ} \mathrm{C}$, the typical temperature windows for practical proton exchange membrane fuel cell (PEMFC) operations, depending on the Au loading amounts ( 0.3 or $0.05 \mathrm{wt} \%$, respectively), as show in Figure 5. Similar to the $\mathrm{Au}_{1} / \mathrm{FeO}_{x}$ catalysts, the $\mathrm{Au}_{1} / \mathrm{CeO}_{2}$ catalysts are also highly stable during PROX reaction, indicating the potential for practical applications.

\subsection{Theoretical studies}

Single metal atoms often strongly bind to support surface atoms, and different supports can offer different anchoring sites to stabilize single metal atoms due to chemical bonding between the metal atoms and the support surfaces. Here we primarily focus on discussing the theoretical understanding of the oxidation states of single gold atoms, the mechanism of $\mathrm{CO}$ oxidation on different metal oxides, and single Au atoms on two dimensional supports. Qiao et al. [25] prepared the ultrastable single-atom gold catalyst $\mathrm{Au}_{1} / \mathrm{FeO}_{x}$ that has excellent performance for $\mathrm{CO}$ oxidation. In order to investigate the oxidation states of $\mathrm{Au}_{1}$ atoms and the change of their charge during the catalytic cycle of $\mathrm{CO}$ oxidation, we employed $\mathrm{Au}(\mathrm{OH})_{x}(x=1-3)$ clusters as reference models for SACs containing $\mathrm{Au}^{+}, \mathrm{Au}^{2+}$ and $\mathrm{Au}^{3+}$, respectively. These models allowed a comparison and evaluation of the Bader charges [25] of $\mathrm{Au}_{1}$ atoms in the stable structures of $\mathrm{Au}_{1} / \mathrm{FeO}_{x}$ with and without oxygen vacancies (Figure 6). The results showed that the oxidation state of the $\mathrm{Au}_{1}$ atoms is close to $\mathrm{Au}(\mathrm{I})$ (with $\mathrm{O}$ vacancies) and $\mathrm{Au}(\mathrm{III})$ (without $\mathrm{O}$ vacancies), indicating electron transfer from the $\mathrm{Au}_{1}$ atoms to the $\mathrm{O}$ atoms of the support. Similarly, the oxidation state of the $\mathrm{Pt}_{1}$ atoms in the $\mathrm{Pt}_{1} / \mathrm{FeO}_{x}$ catalyst [59] can be assigned as either $\mathrm{Pt}(\mathrm{II})$ (with $\mathrm{O}$ vacancies) or $\mathrm{Pt}(\mathrm{IV}$ ) (without $\mathrm{O}$ vacancies), which are isoelectronic with $\mathrm{Au}(\mathrm{I})$ and $\mathrm{Au}(\mathrm{III})$, respectively. These high-valent $\mathrm{Au}_{1}$ atoms provide additional electrostatic interaction with the $\mathrm{O}$ atoms of the support due to the opposite charges of these ions. In addition, the sintering of these non-zero-valent $\mathrm{Au}_{1}$ atoms into subnanometer-clusters

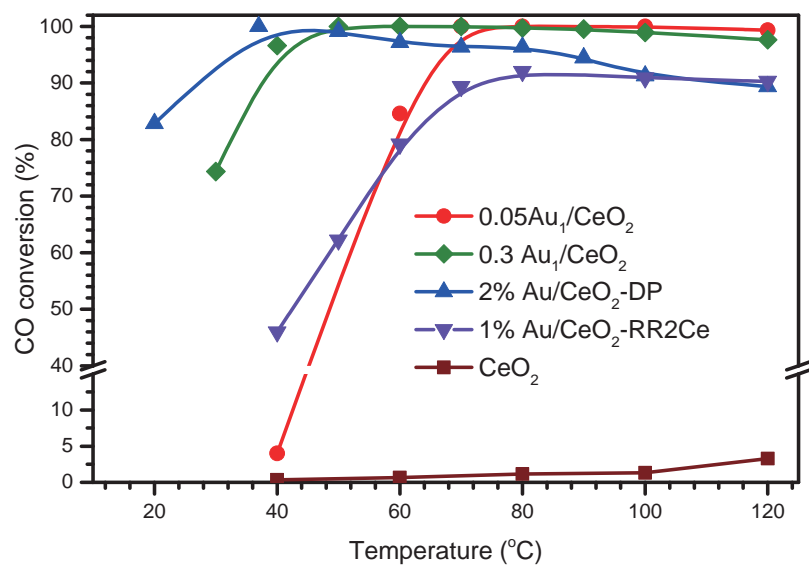

Fig. 5. CO conversion as a function of reaction temperature for PROX on $\mathrm{Au} / \mathrm{CeO}_{2}$ catalysts. Reaction condition: 1 vol\% $\mathrm{CO}+1$ vol $\% \mathrm{O}_{2}+40$ vol $\% \mathrm{H}_{2}$ balanced with He. Weight hourly space velocity (WHSP) $=25$ $000 \mathrm{~mL} \mathrm{~g}_{\mathrm{cat}^{-1}} \mathrm{~h}^{-1}$. Reprinted with permission from Ref. [27]. Copyright 2015, American Chemical Society.

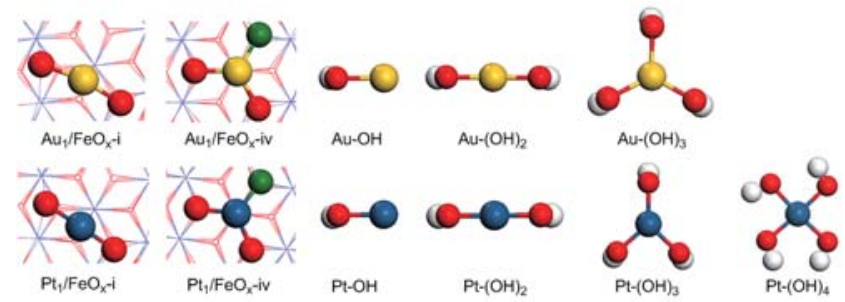

Fig. 6. The stable structures of $\mathrm{Au}_{1} / \mathrm{FeO}_{x}$ and $\mathrm{Pt}_{1} / \mathrm{FeO}_{x}$ with oxygen vacancy (i) and without oxygen vacancy (iv) in pathway I. The $\operatorname{Pt}(\mathrm{OH})_{x}$ $(x=1-4)$ and $\mathrm{Au}(\mathrm{OH})_{x}(x=1-3)$ molecules are calculated in a cubic box of $20 \AA \times 20 \AA \times 20 \AA$. Reprinted with permission from Ref. [25]. Copyright 2015 , Springer.

or nanoparticles becomes energetically demanding because it requires back electron-transfer (i.e., reduction of the $\mathrm{Au}(\mathrm{I})$ and $\mathrm{Au}(\mathrm{III})$ ions) from the adsorbed species or the support and the breaking of the strong $\mathrm{Au}-\mathrm{O}$ bonds to form weaker $\mathrm{Au}-\mathrm{Au}$ bonds in metallic gold. The strong covalent $\mathrm{Au}-\mathrm{O}$ bonding and the high oxidation states of $\mathrm{Au}$ atoms thus account for the exceptional stability and the observed high catalytic activity of $\mathrm{Au}_{1} / \mathrm{FeO}_{x}$ during the $\mathrm{CO}$ oxidation reaction.

Camellone et al. [28] provided insights into the catalytic mechanisms by which single $\mathrm{Au}$ atoms promote the oxidation of $\mathrm{CO}$ on $\mathrm{CeO}_{2}$ (111) surfaces. Their results indicated that the positively charged $\mathrm{Au}$ atoms, substituting for Ce lattice sites, are more active for $\mathrm{CO}$ oxidation. However, these $\mathrm{Au}^{+}$adatoms eventually diffuse into the oxygen vacancies and become negatively charged $\mathrm{Au}^{\delta-}$ adspecies that prevent the adsorption of molecular $\mathrm{CO}$ or $\mathrm{O}_{2}$, thus deactivating the catalyst. Recently, Wang et al. $[60,61]$ performed $a b$ initio molecular dynamics (AIMD) simulations on the well-known low temperature CO oxidation process catalyzed by approximately $1 \mathrm{~nm}$ Au NPs on partially reduced $\mathrm{CeO}_{2}$ and $\mathrm{TiO}_{2}$ supports. They found an unprecedented phenomenon of the dynamic formation of single-atoms from Au NPs on both supports, which they termed as dynamic single-atom catalysis (DSAC). In this DSAC process, the $\mathrm{Au}$ atoms can be carried by adsorbed $\mathrm{CO}$ molecules to migrate on the Au NPs and even migrate to the metal oxide support during the catalytic reaction. A similar phenomenon was reported by a recent work, in which the migration of Au-CO complexes was found to occur on a $\mathrm{Au}$ (111) surface, even at low temperature and low CO pressure [62]. These findings provide another perspective of how the reactants, active sites and the support dynamically interact with one another during a catalytic reaction, especially when the reactants are adsorbed on different sites of a heterogeneous surface.

Yang et al. [31] investigated the CO oxidation behavior of single $\mathrm{Au}$ atoms embedded in two-dimensional $h$-BN monolayers using first-principle calculations, quantum Born-Oppenheim molecular dynamic simulations (BOMD) and micro-kinetic analysis. They determined that $\mathrm{CO}$ oxidation on $\mathrm{Au}_{1} / \mathrm{h}-\mathrm{BN}$ preferentially proceeds via the tri-molecular Eley-Rideal (E-R) reaction mechanism, in which an $\mathrm{O}_{2}$ molecule is activated by two pre-adsorbed $\mathrm{CO}$ molecules. The catalytic activity of $\mathrm{CO}$ oxidation on Au-embedded graphene was also investigated using the first-principle method by Lu et al. [63]. Their data suggest that the first step of $\mathrm{CO}$ oxidation catalyzed by this ma- 
terial most likely proceeds via the Langmuir-Hinshelwood reaction mechanism $\left(\mathrm{CO}+\mathrm{O}_{2} \rightarrow \mathrm{OOCO} \rightarrow \mathrm{CO}_{2}+0\right)$, and that the associated activation barrier is as low as $0.31 \mathrm{eV}$. The second step of the oxidation would be the Eley-Rideal reaction ( $\mathrm{CO}+0$ $\rightarrow \mathrm{CO}_{2}$ ) with a much lower activation barrier of $0.18 \mathrm{eV}$.

\section{Summary}

It has been several decades since Haruta discovered the extremely high activity of supported Au catalysts for low temperature $\mathrm{CO}$ oxidation, and more than ten years have passed since Flytzani-Stephanopoulos discovered that isolated non-metallic $\mathrm{Au}$ species are the active sites for the WGS reaction. However, for various reasons, evidence demonstrating the high activity of $\mathrm{Au}_{1}$ SACs for low temperature CO oxidation has appeared only recently. This mini-review summarized the recent experimental results and that clearly show that, using suitable oxide supports, $\mathrm{Au}_{1}$ single atoms can be as active as Au NPs and clusters when the activity is measured by the true TOF. In addition, when measured by the mass of the $\mathrm{Au}$, which is a critical aspect of industrial applications, the Au SACs exhibit a much higher specific activity, showing the high atom efficiency of SACs. Of more interest and importance, the $\mathrm{Au}_{1}$ SACs are more stable than their Au NPs and clusters counterparts during CO oxidation. These novel features of the $\mathrm{Au}_{1}$ SACs make it possible to develop supported Au catalysts with low cost and high stability which are important for practical applications. On the other hand, studies on $\mathrm{Au}_{1}$ SACs for catalytic reactions are still in the initial stage. Further studies aimed at understanding the nature of catalysis by Au1 SACs and their potential applications for a plethora of catalytic transformations should be explored in the future.

Theoretical calculations, which can provide fundamental understanding and probably prediction of experimental results, have generated helpful information for evaluating the electronic and energetic properties of catalytic processes on an atomic level. It is expected that the further development of computational algorithms not only provide mechanistic details of single-atom catalytic processes but also provide guidance for designing SACs and ultimately are able to predict the activity, selectivity and stability of SACs.

\section{Acknowledgments}

The authors acknowledge of the support by the National Natural Science Foundation of China (21303184, 21503046). J. Liang acknowledges the GZEU startup package. J. Liu acknowledges the support by the US National Science Foundation under CHE-1465057, Arizona State University, and the use of facilities in the John M. Cowley Center for High Resolution Electron Microscopy at Arizona State University. The authors also acknowledge the support by the Strategic Priority Research Program of the Chinese Academy of Sciences (XDB17020100) and the support by Department of Science and Technology of Liaoning Province (2015020086-101).

\section{References}

[1] H. J. Freund, G. Meijer, M. Scheffler, R. Schlogl, M. Wolf, Angew. Chem. Int. Ed., 2011, 50, 10064-10094.

[2] M. Haruta, T. Kobayashi, H. Sano, N. Yamada, Chem. Lett., 1987, 405-408.

[3] M. Haruta, N. Yamada, T. Kobayashi, S. Iijima, J. Catal., 1989, 115, 301-309.

[4] M. Haruta, S. Tsubota, T. Kobayashi, H. Kageyama, M. J. Genet, B. Delmon, J. Catal., 1993, 144, 175-192.

[5] H. L. Guan, J. Lin, B. T. Qiao, X. F. Yang, L. Li, S. Miao, J. Y. Liu, A. Q. Wang, X. D. Wang, T. Zhang, Angew. Chem. Int. Ed., 2016, 55, 2820-2824.

[6] X. W. Xie, Y. Li, Z. Q. Liu, M. Haruta, W. J. Shen, Nature, 2009, 458, 746-749.

[7] Y. B. Yu, T. Takei, H. Ohashi, H. He, X. L. Zhang, M. Haruta, J. Catal., 2009, 267, 121-128.

[8] Y. Lou, X. M. Cao, J. G. Lan, L. Wang, Q. G. Dai, Y. Guo, J. Ma, Z. Y. Zhao, Y. L. Guo, P. Hu, G. Z. Lu, Chem. Commun., 2014, 50, 6835-6838.

[9] K. F. Zhao, H. L. Tang, B. T. Qiao, L. Li, J. H. Wang, ACS Catal., 2015, 5, 3528-3539.

[10] B. T. Qiao, L. Q. Liu, J. Zhang, Y. Q. Deng, J. Catal., 2009, 261, 241-244.

\section{Graphical Abstract}

Chin. J. Catal., 2016, 37: 1580-1587 doi: 10.1016/S1872-2067(16)62529-9

\section{Single atom gold catalysts for low-temperature CO oxidation}

Botao Qiao, Jin-Xia Liang, Aiqin Wang, Jingyue Liu*, Tao Zhang* Dalian Institute of Chemical Physics, Chinese Academy of Sciences, China; Guizhou Education University, China;

Arizona State University, United States

Recent studies revealed that gold single-atom catalysts are not only highly active but also extremely durable for $\mathrm{CO}$ oxidation, which may provide a new way to develop practical Au catalysts with low cost and high stability.

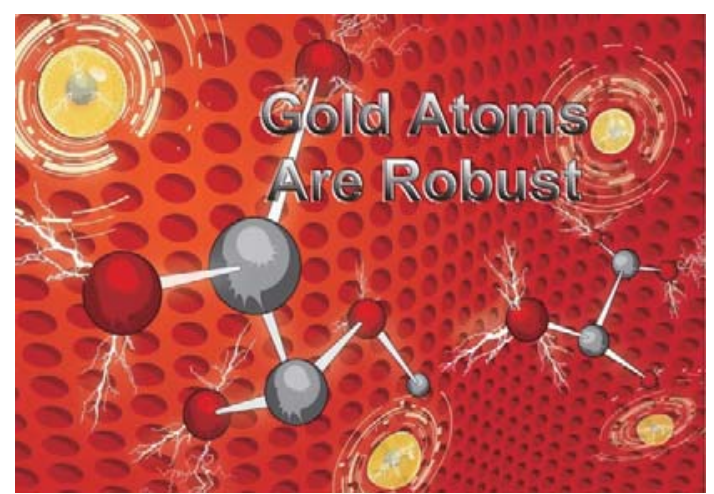


[11] S. Golunski, Platinum Metals Rev., 2013, 57, 82-84.

[12] M. Haruta, Chem. Rec., 2003, 3, 75-87.

[13] M. Valden, X. Lai, D. W. Goodman, Science, 1998, 281, 1647-1650.

[14] B. Hvolbæk, T. V. W. Janssens, B. S. Clausen, H. Falsig, C. H. Christensen, J. K. Nørskov, Nano Today, 2007, 2, 14-18.

[15] A. A. Herzing, C. J. Kiely, A. F. Carley, P. Landon, G. J. Hutchings, Science, 2008, 321, 1331-1335.

[16] M. Haruta, Faraday Discuss., 2011 152, 11-32.

[17] A. Sanchez, S. Abbet, U. Heiz, W. D. Schneider, H. Häkkinen, R. N. Barnett, U. Landman, J. Phys. Chem. A, 1999, 103, 9573-9578.

[18] C. Y. Wang, M. Yang, M. Flytzani-Stephanopoulos, AlChE J., 2016, 62, 429-439.

[19] M. Flytzani-Stephanopoulos, Acc. Chem. Res., 2014, 47, 783-792.

[20] Y. P. Zhai, D. Pierre, R. Si, W. L. Deng, P. Ferrin, A. U. Nilekar, G. W. Peng, J. A. Herron, D. C. Bell, H. Saltsburg, M. Mavrikakis, M. Flytzani-Stephanopoulos, Science, 2010, 329, 1633-1636.

[21] M. Yang, L. F. Allard, M. Flytzani-Stephanopoulos, J. Am. Chem. Soc., 2013, 135, 3768-3771.

[22] M. Yang, S. Li, Y. Wang, J. A. Herron, Y. Xu, L. F. Allard, S. Lee, J. Huang, M. Mavrikakis, M. Flytzani-Stephanopoulos, Science, 2014, 346, 1498-1501.

[23] X. K. Gu, B. T. Qiao, C. Q. Huang, W. C. Ding, K. J. Sun, E. S. Zhan, T. Zhang, J. Y. Liu, W. X. Li, ACS Catal., 2014, 4, 3886-3890.

[24] C. Y. Wang, G. Garbarino, L. F. Allard, F. Wilson, G. Busca, M. Flytzani-Stephanopoulos, ACS Catal., 2016, 6, 210-218.

[25] B. T. Qiao, J. X. Liang, A. Q. Wang, C. Q. Xu, J. Li, T. Zhang, J. J. Liu, Nano Res., 2015, 8, 2913-2924.

[26] B. T. Qiao, J. Lin, A. Q. Wang, Y. Chen, T. Zhang, J. Y. Liu, Chin. J. Catal., 2015, 36, 1505-1511.

[27] B. T. Qiao, J. X. Liu, Y. G. Wang, Q. Q. Lin, X. Y. Liu, A. Q. Wang, J. Li, T. Zhang, J. Y. Liu, ACS Catal., 2015, 5, 6249-6254.

[28] M. F. Camellone, S. Fabris, J. Am. Chem. Soc., 2009, 131, 10473-10483.

[29] Y. G. Wang, D. H. Mei, V. A. Glezakou, J. Li, R. Rousseau, Nat. Commun., 2015, 6, 6511.

[30] Y. G. Wang, Y. Yoon, V. A. Glezakou, J. Li, R. Rousseau, J. Am. Chem. Soc., 2013, 135, 10673-10683.

[31] K. K. Mao, L. Li, W. H. Zhang, Y. Pei, X. C. Zeng, X. J. Wu, J. L. Yang, Sci. Rep., 2014, 4, 5441.

[32] J. Y. Liu, ChemCatChem, 2011, 3, 934-948.

[33] J. C. Fierro-Gonzalez, B. C. Gates, J. Phys. Chem. B, 2004, 108, 16999-17002.

[34] J. Guzman, B. C. Gates, J. Am. Chem. Soc., 2004, 126, 2672-2673.

[35] J. C. Fierro-Gonzalez, B. G. Anderson, K. Ramesh, C. P. Vinod, J. W. Niemantsverdriet, B. C. Gates, Catal. Lett., 2005, 101, 265-274.

[36] J. C. Fierro-Gonzalez, V. A. Bhirud, B. C. Gates, Chem. Commun., 2005, 5275-5277.
[37] J. C. Fierro-Gonzalez, B. C. Gates, Langmuir, 2005, 21, 5693-5695.

[38] J. C. Fierro-Gonzalez, B. C. Gates, J. Phys. Chem. B, 2005, 109, 7275-7279.

[39] V. Aguilar-Guerrero, B. C. Gates, Chem. Commun., 2007, 32103212.

[40] J. C. Fierro-Gonzalez, B. C. Gates, Chem. Soc. Rev., 2008, 37, 2127-2134.

[41] M. M. Schubert, S. Hackenberg, A. C. van Veen, M. Muhler, V. Plzak, R. J. Behm, J. Catal., 2001, 197, 113-122.

[42] L. Li, A. Q. Wang, B. T. Qiao, J. Lin, Y. Q. Huang, X. D. Wang, T. Zhang, J. Catal., 2013, 299, 90-100.

[43] V. Aguilar-Guerrero, B. C. Gates, J. Catal., 2008, 260, 351-357.

[44] V. Aguilar-Guerrero, R. J. Lobo-Lapidus, B. C. Gates, J. Phys. Chem. C, 2009, 113, 3259-3269.

[45] Y. L. Hao, B. C. Gates, J. Catal., 2009, 263, 83-91.

[46] Y. Liu, C. J. Jia, J. Yamasaki, O. Terasaki, F. Schüth, Angew. Chem. Int. Ed., 2010, 49, 5771-5775.

[47] M. S. Chen, D. W. Goodman, Science, 2004, 306, 252-255.

[48] B. T. Qiao, Y. Q. Deng, Appl. Catal. B, 2006, 66, 241-248.

[49] C. M. Zhang, L. Q. Liu, X. J. Cui, L. R. Zheng, Y. Q. Deng, F. Shi, Sci. Rep., 2013, 3, 1503.

[50] C. B. Geoffrey, Surf. Sci., 1985, 156, 966-981.

[51] S. J. Miao, Y. Q. Deng, Chin. J. Catal., 2001, 22, 461-464.

[52] F. Schüth, Phys. Status Solidi B, 2013, 250, 1142-1151.

[53] Q. Fu, H. Saltsburg, M. Flytzani-Stephanopoulos, Science, 2003, 301, 935-938.

[54] H. Sakurai, T. Akita, S. Tsubota, M. Kiuchi, M. Haruta, Appl. Catal. A, 2005, 291, 179-187.

[55] S. T. Oyama, J. Gaudet, W. Zhang, D. S. Su, K. K. Bando, ChemCatChem, 2010, 2, 1582-1586.

[56] J. Gaudet, K. K. Bando, Z. Song, T. Fujitani, W. Zhang, D. S. Su, S. T. Oyama, J. Catal., 2011, 280, 40-49.

[57] M. Yang, J. L. Liu, S. Lee, B. Zugic, J. Huang, L. F. Allard, M. Flytzani-Stephanopoulos, J. Am. Chem. Soc., 2015, 137, 3470-3473.

[58] W. L. Deng, C. Carpenter, N. Yi, M. Flytzani-Stephanopoulos, Top. Catal., 2007, 44, 199-208.

[59] B. T. Qiao, A. Q. Wang, X. F. Yang, L. F. Allard, Z. Jiang, Y. T. Cui, J. Y. Liu, J. Li, T. Zhang, Nat. Chem., 2011, 3, 634-641.

[60] Y. G. Wang, Y. Yoon, V. A. Glezakou, J. Li, R. Rousseau, J. Am. Chem. Soc., 2013, 135, 10673-10683.

[61] Y. G. Wang, D. H. Mei, V. A. Glezakou, J. Li, R. Rousseau, Nat. Commun., 2015, 6, 6511 .

[62] J. Wang, M. McEntee, W. J. Tang, M. Neurock, A. P. Baddorf, P. Maksymovych, J. T. Yates Jr., J. Am. Chem. Soc., 2016, 138, 15181526.

[63] Y. H. Lu, M. Zhou, C. Zhang, Y. P. Feng, J. Phys. Chem. C, 2009, 113, 20156-20160.

\section{金单原子催化剂上一氧化碳低温氧化

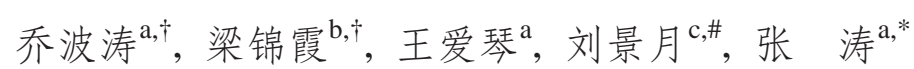 ${ }^{\mathrm{a}}$ 中国科学院大连化学物理研究所催化基础国家重点实验室, 辽宁大连116023 \\ b贵州师范学院贵州省纳米材料模拟与计算重点实验室, 贵州贵阳550018 \\ c 亚利桑那州立大学物理系, 坦佩, 亚利桑那州85287, 美国}

摘要: CO 低温氧化对于基础研究和实际应用均具有重要意义. 自上世纪八十年代日本的 Haruta 教授发现氧化物负载金催 化剂对 CO 氧化的超高活性以来, 负载金催化剂受到了广泛关注与深入研究, 被认为是目前活性最高的 CO 氧化催化剂. 在诸多影响 CO 氧化活性的因素中, 纳米金的粒子尺寸是最重要因素之一. 目前主流观点认为对于 CO 氧化, 纳米金有一 个最优尺寸范围, 在 $0.5-5 \mathrm{~nm}$, 而 $\mathrm{Au}$ 原子/离子 $\left(\mathrm{Au}^{3+}, \mathrm{Au}^{+}\right)$的活性则低一到两个数量级. 因此, 一般认为负载金单原子催 
化剂对于 $\mathrm{CO}$ 氧化反应的活性要比金纳米粒子和团簇低很多. 然而, 最近几年的理论与实验研究均表明, 金单原子负载于 合适的载体上可以显示出与金纳米粒子和团簇相当的活性. 本文对这些新进展进行综述, 阐述金单原子催化剂对 CO 氧化 的独特反应性能.

Gates 教授研究组进行了大量关于正价金对 $\mathrm{CO}$ 氧化影响的研究, 其中包括孤立的金原子 $\left(\mathrm{Au}^{+}\right)$. 他们的研究发现, $\mathrm{CO}$ 氧化活性随价态降低而降低, 表明正价金对 CO 氧化至关重要. 此外, 他们的研究也表明, 孤立金原子对 CO 氧化的活性 (TOF) 比金纳米粒子低一到两个数量级. 然而, 在他们的研究中, 有几个因素可能导致催化剂的低活性. 首先, 他们一般采 用非或弱还原性的载体. 而载体的还原性对金催化剂上 CO 氧化活性影响非常巨大. 另外, 他们所用的金原子前驱体为配 合物, 在催化剂制备与反应过程中配体并没有去除, 可能也是导致催化剂活性低的原因之一.

与此相反, 张涛课题组近期采用氯金酸为前驱体, 通过简单的吸附浸渍法制备了一系列负载金单原子催化剂. 同时用 相同的载体制备了负载金纳米粒子催化剂进行对比, 可以排除载体等其它影响因素. 对比结果显示, 单原子催化剂均显示 出与纳米粒子相当的 $\mathrm{TOF}$ (单位表面 $\mathrm{Au}$ 原子) 和更高的反应速率 (单位重量金).

首先制备了氧化铁负载金单原子催化剂, 该催化剂在室温即展现出可观活性, TOF 值与 2-3 nm金粒子 TOF 值相当 $\left(\sim 0.5 \mathrm{~s}^{-1}\right)$. 更有趣也更重要的是, 该催化剂在高温 $\left(200^{\circ} \mathrm{C}\right.$ 以上) 展现出非常高的反应稳定性, 在 $200{ }^{\circ} \mathrm{C}$ 应 $100 \mathrm{~h}$ 无失活. 在 300 和 $400{ }^{\circ} \mathrm{C}$ 反应 $50 \mathrm{~h}$ 也无失活发生, 为开发高温稳定的金催化剂提供了新途径. 其次制备了氧化钴负载金单原子催 化剂, 该催化剂以 $0.05 \%$ 金负载量即可实现室温全转化, 其 TOF 值高达 $1.4 \mathrm{~s}^{-1}$. 然而该催化剂在达到高活性之前必须首先 在反应气氛中进行高温处理, 这限制了其实用性. 此外, 催化剂需经反应气氛活化的原因尚待进一步研究. 随之又制备了 氧化铈负载金单原子催化剂, 对富氢条件下 CO 选择氧化不仅具有高活性, 而且具有极高的 CO 选择性. 进一步研究结合 理论计算表明, 高选择性来自氧化铈负载的金单原子不能解离活化氢, 对于氢气氧化活性极低, 从而导致 CO 氧化的高选 择性.

理论研究方面也有进展. Camellone 等计算发现金原子可以取代 $\mathrm{CeO}_{2}(111)$ 面上的 $\mathrm{Ce}$ 原子形成 $\mathrm{Au}^{+}$并促进 $\mathrm{CO}$ 氧化. 然而该金原子会扩散至氧空位形成带负电荷的 $\mathrm{Au}^{\delta-}$, 阻止 $\mathrm{CO}$ 和 $\mathrm{O}_{2}$ 吸附, 因而使催化剂失活. 李隽课题组利用从头算分子 动力学模拟首次发现氧化铈和氧化钠负载的 $\mathrm{Au}$ 纳米粒子在 $\mathrm{CO}$ 氧化过程中可以形成单原子的现象, 并将之称为动态单原 子催化剂. Yang 等则计算了二维材料 $\mathrm{BN}$ 负载 $\mathrm{Au}$ 单原子催化 $\mathrm{CO}$ 氧化并发现反应优先通过三原子 $\mathrm{E}-\mathrm{R}$ 机理进行.

关键词: 金; 单原子催化剂; 一氧化碳氧化; 稳定性; 低温

收稿日期: 2016-06-01. 接受日期: 2016-08-23. 出版日期: 2016-10-05.

*通讯联系人. 电话: (0411)84379015; 传真: (0411)84685940; 电子信箱: taozhang@dicp.ac.cn

\#通讯联系人. 电子信箱: Jingyue.Liu@asu.edu

这些作者对本文工作具有同等贡献.

基金来源：国家自然科学基金(21303184, 21503046); 美国国家科学基金 (CHE-1465057); 中国科学院战略性先导科技专项 (XDB17020100); 辽宁省科技厅院士基金 (2015020086-101).

本文的英文电子版由Elsevier出版社在ScienceDirect 上出版(http://www.sciencedirect.com/science/journal/18722067). 